\title{
Comparison of Canadian Urban and Small-town Exhibition Practices 1914-1929
}

\begin{abstract}
Because of Canada's geographic location, the business of film exhibition has always been tied to the United States and ultimately controlled by Hollywood. In order to understand the historical cinematic experience of Canadians in different regions, this paper seeks to compare opening playdates in urban Canada to the northern mining community in Timmins, Ontario from 1914 to 1929, a pivotal period during which Paramount controlled Famous Players came to dominate both film exhibition and distribution in the country. I also analyse holiday programming at Christmas and Easter during this same time period. My analysis demonstrates that there was a variance of film premiere dates throughout urban Canada. This article also shows that even though small towns like Timmins had films much later than urban locations they were still able to create a unique cinema culture through special programming during holidays that was unique from other locations in Canada.
\end{abstract}

\section{Keywords}

New Cinema History; comparative research; urban vs. rural; Canada

\section{Introduction: comparing urban and small-town filmgoing in Canada}

On August 3, 1925, the Montreal Gazette published an article on the opening of Cecil B DeMille's The Ten Commandments. The newspaper noted that the premiere screening in Montreal happened almost a full year after it had been shown in most other cities in North America including in other large Canadian cities such as Toronto and Vancouver. Even smaller cities, like the border town of Windsor had screened the film several months before it was shown in Montreal, which was then Canada's largest city. Going to the movies in urban Canada, especially in the metropolis of Toronto, generally meant that urban patrons would often see a film several months to even years before their small-town counterparts would view the same film. The long wait times to see new releases was also true in some urban centres based 
on cultural and geographic divides. These went beyond urban and rural, including the divides between French and English and Eastern and Western, which both led to variances in film premiere dates. These cultural and geographic divides, in terms of film exhibition history in the country, provide an interesting point of comparison for data driven research within New Cinema History.

This paper seeks to analyse the patterns of premiere dates and film programming between a selection of urban areas across Canada to the mining town of Timmins, Ontario, which is located in Canada's isolated region of Northern Ontario (Figure 1). Timmins provides an interesting base of comparison because it was the headquarters of Leo Mascioli’s Northern Empire chain, which dominated film exhibition in the region and was able to remain independent from Paramount controlled Famous Players Canadian longer than most other chains in the country. ${ }^{1}$ The Timmins newspaper, the Porcupine Advance has also recently been digitised allowing for easier comparative research. In order to compare historical film exhibition between small town and urban areas in Canada, I will (1) compare premiere dates of the top grossing films of the 1910s and 1920s using

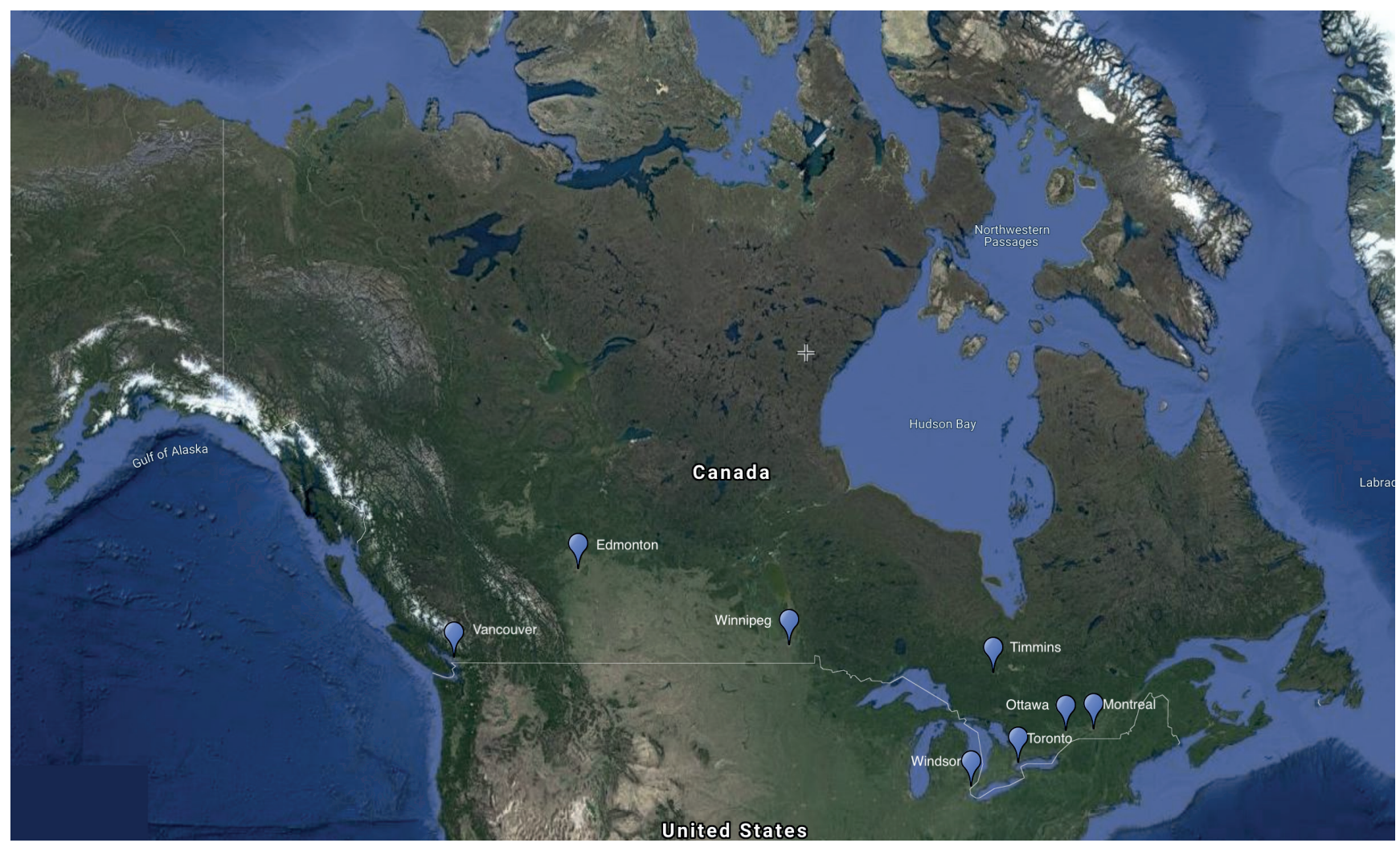

Figure 1. Map of Canada and locations studied in this research (source: google map pro). 
selected locations and digitised newspaper databases (2) I will then also compare film programming in Timmins at Christmas and Easter to when these same films were screened in selected areas in Canada from 1919 to 1929 again using digitised newspaper databases.

This work uses data originally collected for a local case study and expands this research to compare to larger national trends. Although local case studies, which have become the norm for much of New Cinema History research, are important to understand cinemagoing trends in specific areas, it is also important to expand these case studies in order to investigate how cinemagoing practices differed across time and space. My original study of the town of Timmins and its movie theatres was a microhistory of cinemagoing practices in one small town. Although my previous work gave insight into the unique features of film exhibition in Timmins, by opening up my study to comparative work, I am able to both highlight these unique features as well as analyse the specific differences between Timmins and urban Canada by using a comparative framework. A general criticism of New Cinema History is that it is a collection of case studies and in order for scholars to counteract this criticism, we must work to expand these local case studies in order to understand how these microstudies fit into larger national and international moviegoing trends.

This article answers the call from Biltereyst and Meers for more systematic comparative research in New Cinema History. ${ }^{2}$ They have invited scholars to move beyond local case studies and to develop a comparative perspective that addresses 'larger trends, factors or conditions explaining differences and similarities in cinema cultures' and utilises a research design that includes 'a thoughtful, systematic comparison of cinematic phenomena across different geographic or temporal entities. ${ }^{3}$ Because of Canada's large and varied population a comparative approach is necessary in understanding how the country's vastly different populations went to the movies. A key question when it comes to the differing cinematic experience of Canadians, is when each location gained access to first run films, and the length of time it took for films to open in remote locations. Within urban Canada it is also important to explore which cities had the earliest access to films. My analysis is a micro comparison under the definition written by Stefan Berger. Berger codified a typology of historical comparison and wrote that regional or micro comparisons may in fact be more useful to understand the totality of certain phenomenon. ${ }^{4}$ In this case a regional comparison between a small town compared to urban locations in Canada demonstrates how film distribution differed throughout the country. 
As Judith Thissen writes in her introduction to Cinema Beyond the City, the history of film history is rooted in the metropolis, although there are several works that have addressed the unique features of going to the movies in small towns, which have mostly focused on Northern Europe and the United States. ${ }^{5}$ In Canada, there have been some studies that have explored moviegoing in small towns; however, most Canadian studies have only looked at small towns with monoethnic populations and agrarian-based economies. ${ }^{6}$

As a mining town, Timmins is somewhat of an anomaly in the context of small-town exhibition studies because of its population and economy. Timmins was not entirely rural, because of its population and demographics, but it was also not urban because of its remote location despite having the population and demographics of a substantial, mid-sized town. It also had a multiethnic population that came in different waves of migration. Most of the early settlers were French and English Canadian with First Nations peoples living on the periphery. Italians, Ukrainians, and Finnish immigrant workers were later brought in to work in the mines, and there was also a small Chinese population in the town. Timmins's population rapidly expanded between 1921 and 1941 from 3,839 to $29,140 .{ }^{7}$ Even though by the 1940 s Timmins was the size of a mid-sized town in Canada, the population did not have access to the same amenities as comparable towns in the south because of its remote northern location making it an important point of comparison to the rest of urban Canada.

\section{An overview of film exhibition studies in Canada: the need for more comparative work}

In terms of comparative work not much has been done to explore film distribution in different regions in the country, instead most studies focus on the overall unequal power relationship between Canada and the United States as well as English Canada's reliance on Hollywood film and its industry. The basis for much of historical film exhibition and distribution studies in Canada is the work of Peter Morris whose book Embattled Shadows traced Canada's reliance on foreign media from vaudeville to later vertical integration of the industry through Hollywood controlled Famous Players Canadian Corporation. Canada's small population, spread out over a vast landmass, made it untenable for a national entertainment industry to evolve. This was particularly true in English Canada where readymade entertainment products in the same language could be easily imported 
from the United States who had built a national film industry by the second decade of the twentieth century with vertically integrated film companies and theatre chains.

Most other studies concerned with the history of film exhibition in Canada have also explored the film industry, but largely only in the context of how Hollywood came to dominate movie screens in Canada and inhibit domestic film production. In the 1990s, several book-length policy studies grappled with the effects of Hollywood on the film industry in Canada with a view to advancing the development and efficacy of government film policies. ${ }^{8}$ Each of the books by Pendakur, Jarvie, Dorland, and Magder looked at the larger business of film in Canada. Paramount's direct ownership of Famous Players Canadian is a continually looming problem, alongside effective political lobbying by Hollywood through the Motion Picture Producers and Distributors Association. All of these studies looked in depth at the political economy of the industry and focused on the national industry as a whole in relation to policy, politics, and economic integration with Hollywood corporations. With a foundational, nationalist concern for cinema as a creative industry, these works only focus on the business of film for its impact on the political economy of Canadian filmmaking, rather than seeking to understand the audience or the context of local cultural practices. This approach has been labelled the 'policy reflex' by Ira Wagman, who notes it applies widely to communication studies in Canada across all media. ${ }^{9}$

In contrast to the earlier 'policy reflex' in Canadian film histories, more recent studies have begun to look at historical case studies of film cultures in Canada. A foundational text is Zoë Druick's book Projecting Canada, which examined the policy, history, and film production of the National Film Board. While Druick still looks at policy, she provides a holistic study of the National Film Board and examined how the organisation fostered a specific Canadian film culture. ${ }^{10}$ Another recent example is Monika Kin Gagnon and Janine Marchessault's book Reimagining Cinema: Film at Expo 67, which looked at how the Expo helped to reshape not only Canadian film, but also exhibition practices. ${ }^{11}$ Case studies of Canadian exhibition practices are a key element to this new Canadian film history with important contributions from Peter Lester and Louis Pelletier. ${ }^{12}$ Another influential figure in Canadian film exhibition studies is Paul Moore, who utilises newspaper accounts and archival records to demonstrate the emergence of moviegoing culture and how going to the movies became connected with identity and even citizenship in Canada. ${ }^{13}$ Moore has focused on the importance of early exhibitors in the proliferation of cinema across Canada with a focus on the central role of Toronto, its moviegoing practices, and influence on the wider industry in 
Canada. ${ }^{14}$ Although Canadian film distribution was largely 'part of the American domestic circuit, just another region on the continent,' Toronto was head office for vertically-integrated theatre chains, and in turn national headquarters for distribution. ${ }^{15}$ Like New York and later Los Angeles, Toronto was the base for film exchanges in Canada and the city played a central role in the film industry, particularly in English Canada.

The business histories of film are especially important in Canadian film history as they provide key insights into the development of the industry in Canada. As Peter Morris and Paul Moore have argued, because there was no early internal film industry in Canada, early Canadian film history is entirely based on exhibition practices. Thus, any history of film in Canada should focus on local exhibition and distribution practices, but most research has solely focused on urban moviegoing. ${ }^{16}$ However, most Canadian studies on moviegoing outside of large cities have not focused on comparative data, and like much of New Cinema History rely on local case studies. Although Paul Moore does provide a sociological look at the history of film exhibition in Canada and he has conducted several comparative pieces demonstrating filmgoing practices, there needs to be more comparative work particularly looking at areas outside of large city centres. ${ }^{17}$ In order to fully understand the differing experiences of moviegoing between urban and small town locations, more comparative data and analysis is needed.

\section{Early film in Canada: the building of an industry}

There has always been a close connection between Canada and the United States in the film business from the earliest days of film exhibition. While many European countries had an 'inventor' who introduced a film machine independently from Edison, in Canada there were only franchise holders for the technology. Thus, from its earliest stages, the film industry in Canada had a dependent relationship with the United States. Even in the silent film period when costs were relatively cheap, Canadian exhibitors could not compete with American companies. ${ }^{18}$ Canadians would sometimes invest in the emerging industry but usually only in companies with structural ties to the United States. ${ }^{19}$ As with other businesses operating branch-plants in Canada, when the U.S. border acted as a complication against the extension of American film industry practices in the north, companies integrated Canada into their business operations through outright ownership of Canadian subsidiaries. ${ }^{20}$ 
A distinguishing feature of small-town and rural filmgoing in Canada was how long it took for purpose-built theatres to come to remote regions. While nickelodeons started to appear in metropolitan areas in 1905 and 1906 in Canada, many smaller towns and peripheral areas went without dedicated movie theatres until the 1910s and before then were serviced largely by itinerant traveling shows. The earliest mentions of film in the Northeast Ontario region, where the Northern Empire Chain, based in Timmins, was located, were in Sudbury and North Bay, both in $1897 .{ }^{21}$ In 1904, another traveling show came to the region when the London Bioscope Living Canada films were shown in Sudbury. ${ }^{22}$ It is hard to determine the scale of the early film programming available in the mining communities of the Northeast because there are not many newspapers that predate 1905 in the archives. One of the earliest newspapers in the region is from the town of New Liskeard, which, since 2004, has become part of the amalgamated city of Temiskaming Shores. Paul Moore discovered periodic early picture shows in New Liskeard, and in 1907, there was a weekly traveling circuit from North Bay to Englehart with shows likely presented in Cobalt, Haileybury, and New Liskeard, and this circuit would show films for one night at each place weekly. ${ }^{23}$

Before Leo Mascioli came to Timmins to start his Northern Empire chain, he was in Cobalt during the silver rush. It is not known if he had any involvement with film exhibition at that point in his career, but he must have been influenced by the mining town's vibrant leisure culture during its silver rush. Cobalt during the 1910s was a booming mining town with five theatres. The Orpheum, Lyric, Empire, and Idle Hour theatres all had a combination of vaudeville and film programming, with ads for the Bijou promoting a program consisting only of moving pictures. In Cobalt, workers lived adjacent to the mines, and while mining companies created social clubs that showed moving pictures, musical shows, and public lectures, miners would often take the streetcar into town on Saturday nights. ${ }^{24}$ The downtown of Cobalt was filled with restaurants, poolrooms, saloons, burlesque halls, oyster bars, shooting galleries, brothels, and theatres. Because of the Miners Act, which did not allow for the sale of intoxicating liquor near mines, there were also several bootlegging underground establishments in the town. ${ }^{25}$

As with the later situation in Timmins, when specific films at any of the theatres in Cobalt were advertised, they were shown at least a few months after they played in other locations, but nevertheless the theatres did often screen fairly recent releases. On January 21, 1910, The Cobalt Nugget reported that the Johnson Ketchel Fight Picture would be shown at the Idle Hour Theatre. The fight took place on October 16, 1909 and was shown throughout the United States in November 1909. 
It also premiered in Toronto during the week of the November 15, 1909. The film played throughout Canada from November to January including in Vancouver in December, and it also played in the Western city of Regina around the same time in January as the Cobalt screening. This indicates that Cobalt screened the film around the same time as many other places in Canada despite its remote locations. Although this was not always the case in other mining communities in the region.

While it does appear Cobalt, given its boom town status, had fairly recent films, this was not true for much of the region. In 1919, The Moving Picture World published a report on the unique problems of showing films in the Canadian North, which focused on theatres in the Temiskaming region and is also located in Northern Ontario. The report mentioned that programming at the theatres was not the typical five-reel productions, which were becoming the norm in most theatres across North America, and instead exhibitors screened two-reel subjects of 'ancient vintage.' The theatres also exhibited out-dated newsreels, and it was reported that 'release dates are of no consequence to these Northerners. ${ }^{26}$ ' The issue of gaining access to current films was one that was repeated later in Timmins with many newspaper reports in early issues of the Porcupine Advance on the difficulty of getting films from Toronto.

Despite the popularity of theatres in Cobalt, a successful regional chain did not evolve from the theatres in the town, most likely due to the fast decline or bust of the Cobalt silver rush. Much like Dawson City, Cobalt had a fast rise and decline with the population figures declining from 10,000 in 1909 to 5,638 in 1910. It was Timmins, with its longest sustained gold rush in North America, that became the base for the largest chain in the region - Leo Mascioli's Northern Empire theatre chain. Mascioli's first theatre in Timmins the Empire Theatre opened in 1911 during the early stages of the town's development. The early theatres in Timmins were improvised structures, and the first Empire Theatre was built in a converted store that used kitchen chairs as seats and had a makeshift two-byfour projection booth built over the front door. A year later, a newer Empire Theatre was built, which Mascioli described in a 1939 interview with the Timmins Daily Press as an 'ungainly building'. ${ }^{27}$ This second Empire Theatre was larger but was plagued with technical problems and the company also had difficulty getting quality films from distributors in Toronto according to The Porcupine Advance. ${ }^{28}$

The theatres evolved with the town, and in 1916, Mascioli opened Timmins' first modern theatre, the New Empire Theatre, with 600 seats and an opulent stage and design. In 1924, a second modern theatre opened, the Goldfields Theatre, with 847 seats. The popularity of the theatres started to increase dramatically, and in the 1920s, the Porcupine Advance reported that the theatres 


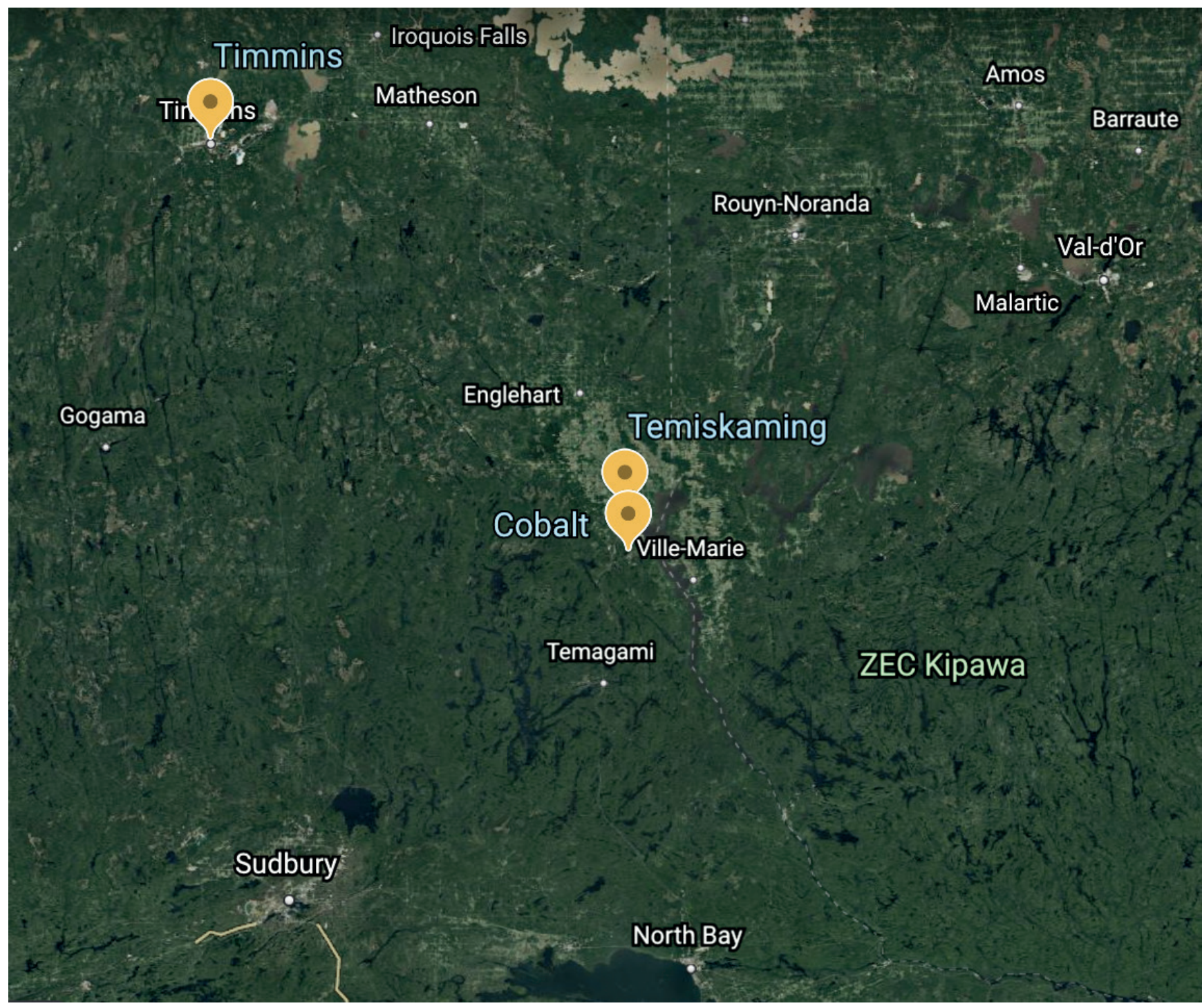

Figure 2: Map of Northeastern Ontario.

began to mimic the programming of theatres in larger cities with two shows every evening. ${ }^{29}$ The leisure practices of the town began to shift in the 1920s. Nancy Forestell argues that the earlier homosocial leisure culture of the 1910s was dismantled in the 1920s as the mining companies tried to make the former campsite into a family-friendly community. It was during this period that the illegal drinking establishments known as blind pigs and brothels decreased; married men began to partake in family-centred recreation and single men began interacting more frequently with single women in social settings. ${ }^{30}$ Theatres functioned as important spaces for this new type of 
mixed-gendered/family-centred leisure to take place. The theatres also helped to create a unified community and as Paul Moore points out, 'having a local encounter with cinema, and having local scenes filmed, was thus linked to being modern and civilised.'31 The early shows that exhibited both local and international films helped to shape these mining communities and the immigrant populations of the region.

\section{Famous Players Canadian and exhibition practices across the country}

The motion picture industry in Canada lent itself to a nationwide theatre chain that was ultimately controlled by Hollywood. This is because Hollywood companies were already involved with production, distribution, and exhibition on a national scale across the United States and it was relatively simple to continue their operations north to Canada. While there was legislative and popular sentiment against chain stores pushing out 'mom and pop' operations, particularly in the United States, the theatre industry was different because it still allowed (indeed needed) small theatre owners to continue to operate as second- or third-run options in the majority of lessprofitable smaller towns and rural areas. The theatres owned by the Hollywood studios were predominantly larger, first-run movie palaces in prime metropolitan locations that charged a premium ticket price and reaped a disproportionate amount of the industry's profits. While other industry's chain stores could undercut small town stores in price because of economies of scale advantage, industry-owned theatres generally charged more than independents because of their exclusive franchise for first-run films. ${ }^{32}$ The creation of a national Canadian theatre chain that focused on first-run theatres was a natural extension of what was happening concurrently in the United States.

Famous Players Canadian was started as a partnership between Paramount's Adolph Zukor and Toronto-based showman Nathan L. Nathanson. In 1918, Adolph Zukor started on a theatre 'buying spree' after securing financing from Wall Street, in a bid to counteract the emerging competition of Associated First National, an allegiance of exhibitors who had begun production with some of the biggest stars. ${ }^{33}$ Before the creation of Famous Players Canadian, the Allen family chain had become by far the largest theatre circuit in Canada during the years 1917 to 1919, building new movie palaces across the country on the basis of their Paramount distribution franchise for Famous Players-Lasky 
productions. To establish direct control of theatres in Canada, Zukor first approached the Allen family to become partners, but they refused. According to census records, Jules Allen lived directly beside Nathan L. Nathanson on St. Andrews Gardens in the Rosedale neighbourhood in Toronto. ${ }^{34}$ When Nathanson heard that the Allen family rejected Zukor's deal, he started negotiations to become partners with Paramount. In 1919, the Allen family lost the Paramount franchise and instead aligned with First National. Famous Players Canadian was started on February 5, 1920, with Nathanson at the helm. The company began a building-boom of new Capitol movie palaces, backed by preferential treatment from a new group of Paramount distribution branches across Canada established by Zukor himself. 35

Famous Players Canadian soon came to dominate the movie exhibition industry in Canada and quickly surpassed the Allen circuit, buying most of their assets in 1923, and also acquiring many other small-chain and independent theatres across the country. A key aspect of the history of Famous Players Canadian's expansion across Canada was Nathanson's ability to coerce independent exhibitors into partnership agreements. Nathanson had three main tactics in getting exhibitors to sign with him: first, in his exclusive control of vaudeville booking contracts, Nathanson would prevent live acts from playing in non-Famous Players Canadian theatres - as important as limiting access to films, recalling that the 1920s were still the silent-film era; second, he would build or begin plans to build new theatres near independent theatres in order to undercut their businesses; and third, he would lure exhibitors into signing contracts by telling them that they could rent Paramount films at a much lower rate - and implicitly threaten to cut their supply if not. ${ }^{36}$ By 1930, Famous Players Canadian owned 207 out of the 1,108 theatres in Canada - almost all of the largest and most profitable first-run downtown theatres in every major city. ${ }^{37}$ Along with acquiring theatres, Famous Players Canadian came to dominate distribution. In addition to being president of Famous Players Canadian, Nathanson also headed a film exchange called Regal Films, which eventually distributed films by MGM and other studios - in total, 36 percent of all films in Canada by $1930 .{ }^{38}$ Block booking, where a theatre had to contract for an entire season with a distributor, came into practice in the 1920s in Canada, which resulted in those theatres that were affiliated with Famous Players Canadian having an advantage over independent theatres because they always had preference to pick the newest, best films, while independents had to select from a predetermined list for an entire season. ${ }^{39}$ 


\section{Determining the top films of the $1910 \mathrm{~s}$ and $1920 \mathrm{~s}$}

Canada has always been treated as part of the domestic market by the American trade press. Because of this, US trade paper figures can be used to determine the most popular films of the time. Unlike later eras where there is a ubiquity of box office data compiled, the transformative era and even into the 1920s, there are not many top grossing lists of films for each decade available in digitised online periodicals. My list of films was created using two 'all-time best sellers lists' found in a 1934 article in Motion Picture Herald and another list from the 1937/38 International Motion Picture Almanac, which includes many films from the teens and twenties. Both lists include the title of the film, the year it was released, and the total rental amount made in North America. This combined list (Figure 3) of films from the teens and twenties includes The Singing Fool, Four Horsemen of the Apocalypse, Ben Hur The Big Parade, Birth of a Nation, The Covered Wagon The Jazz Singer, The Gold Rush, The Kid, The Ten Commandments, Daddy Long Legs, The Miracle Man, and The Spoilers. There are some limitations to this list as it is not specific to just Canada, but during this time period the Canadian industry did not publish its own yearbook nor did the Canadian government under the Dominion Bureau of Statistics release specific film titles in their calculations of Motion Picture Statistics in the country, which they started compiling in 1930.

Using the above list, I compared opening dates in Timmins to the larger Canadian cities of Toronto, Winnipeg, Vancouver, Montreal, Edmonton and Ottawa. I also recorded the opening dates for the smaller city of Windsor, located on the United States border at Detroit, which is actually located to the north because of a twist to the international boundary here. My reasoning for including Windsor is that the local newspaper often advertised films from the Detroit theatres and encouraged people to cross the border to see these films. All of the newspapers used from each of the locations listed above, except for Toronto, are contained in the newspapers.com database, which has excellent OCR recognition and I was able to find opening dates for all of the films. Unfortunately, the Toronto papers were digitised earlier than the others and are hosted on the less user-friendly ProQuest site, which made finding opening dates more difficult, but I was also able to find every film on my list mostly relying on the "what's playing" column which noted all new films to open in the city. The Timmins opening dates were found using the newly digitised Porcupine Advance, which was digitised in 2018, and is available on the publicly accessible Ontario Community Newspaper Portal. Although this site is less user friendly than newspapers.com, the OCR of the Porcupine Advance is excellent. I 


\begin{tabular}{|c|c|c|}
\hline Film & Release Year & Rental Amount \\
\hline The Singing Fool & 1928 & $\$ 5,000,000.00$ \\
\hline Four Horsemen of the Apocalypse & 1921 & $\$ 4,500,000.00$ \\
\hline Ben Hur & 1926 & $\$ 4,000,000.00$ \\
\hline The Big Parade & 1925 & $\$ 3,500,000.00$ \\
\hline Birth of a Nation & 1915 & $\$ 3,500,000.00$ \\
\hline The Covered Wagon & 1923 & $\$ 3,500,000.00$ \\
\hline The Jazz Singer & 1927 & $\$ 3,500,000.00$ \\
\hline The Gold Rush & 1925 & $\$ 2,500,000.00$ \\
\hline The Kid & 1921 & $\$ 2,500,000.00$ \\
\hline The Ten Commandments & 1923 & $\$ 2,500,000.00$ \\
\hline Daddy Long Legs & 1919 & $\$ 1,250,000.00$ \\
\hline The Mircle Man & 1919 & $\$ 1,000,000.00$ \\
\hline The Spoilers & 1914 & $\$ 1,000,000.00$ \\
\hline
\end{tabular}

Figure 3: Best sellers of the 1910s and 1920s.

was able to find opening dates for all except two films on my list, the Jazz Singer and Daddy Long Legs which do not seem to have played in Timmins ${ }^{40}$ This could be due to database or OCR issues, which is an inherent problem with relying on digitised materials. All of the dates opening dates were determined by looking at both advertisements, which indicated premieres, and also articles in newspapers which reported on the premieres. Reporting on when a particular film was first screened was typical in newspapers in both urban and smaller locations in Canada. 


\section{Opening date comparisons 1914-1930}

The comparative data demonstrates that four out of the thirteen best seller films had their Canadian premiere in Toronto. There were also premieres in Montreal, Vancouver, Ottawa, and Winnipeg (Figure 4). The fact that only four premieres happened in Toronto is surprising. Montreal, Toronto, and Windsor all played films relativity close together although again there were the notable exceptions in the case of Montreal when The Ten Commandments screened almost a year after it was first shown in Toronto and Windsor. Canada's capital city, Ottawa generally screened films within a few months of the Canadian premiere and was the location of one premiere, but there were several cases when a film screened well past its first release in other Canadian cities. In the case of The Covered Wagon, it was reported in the Ottawa Journal in a paid column by the proprietors of the Auditorium Theatre that the reason the film took so long to get to Ottawa was because of Famous Players insistence that ticket prices be increased for the film. ${ }^{41}$

In Western Canada, Vancouver had one premiere and Winnipeg also had one notable opening with Chaplin's The Kid at the Allen Theatre, which showcases some of the pre-1923 divides between Famous Players and the Allen circuit. As mentioned above, Famous Players was aligned with Paramount while the Allen's had a deal with Frist National, which distributed The Kid. By 1921, the Allen family still had several first run options in Winnipeg and only one in Toronto, which seems to be why Winnipeg was chosen to be the premiere location. It is also notable that the Allen's exclusively advertised this film in the Winnipeg Free Press and there were no advertisements in the other daily newspapers, which leads to several further questions regarding the advertising of film premieres in Canada. In particular it leads to question why any film premiere would not have been advertised in all daily newspapers. It also questions the relationship between theatres chains and daily newspapers and if chains had exclusive deals with some newspapers in terms of advertising. Other than this one case, Edmonton and Winnipeg generally had consistent opening dates, with films from the best sellers list usually playing within days or weeks of each other, although Vancouver sometimes would screen films several months in advance of Edmonton and Winnipeg, and there does not appear to be a consistent pattern between all three western locations.

As mentioned above, the Windsor Daily Star regularly advertised programming at the Detroit theatres and three pictures on the best seller list were advertised in that paper first. Readers in Canada's ‘border' city were encouraged to travel to Detroit to see films before other Canadian 


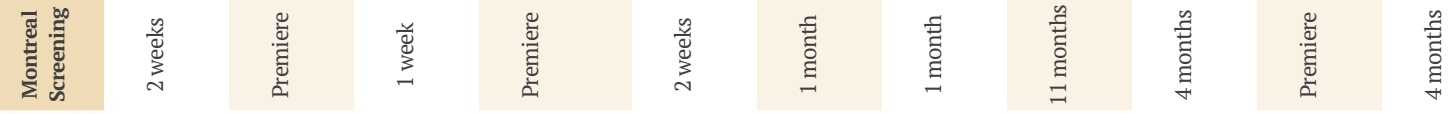

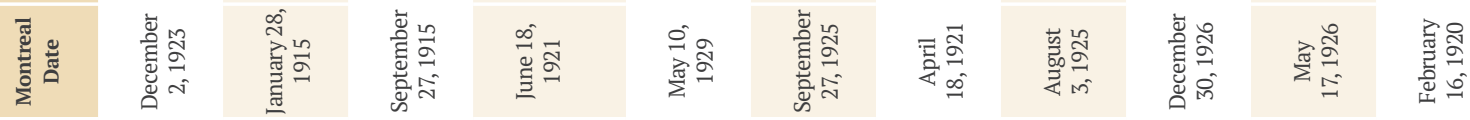

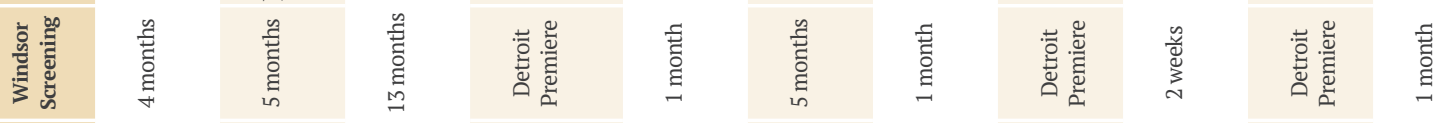

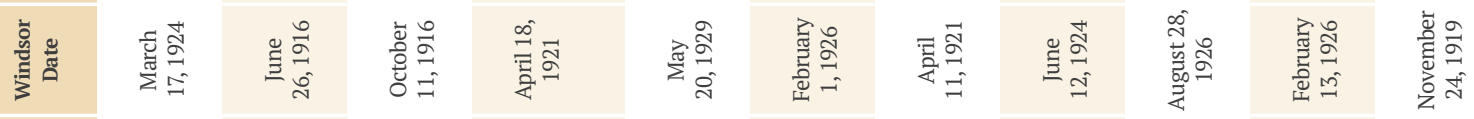

II

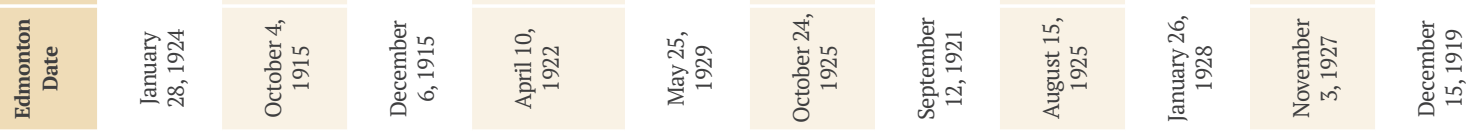

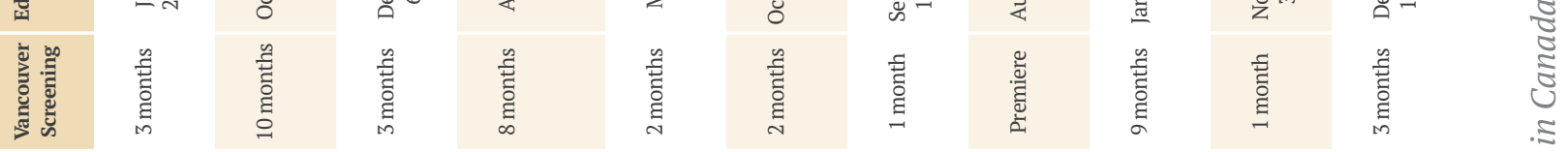

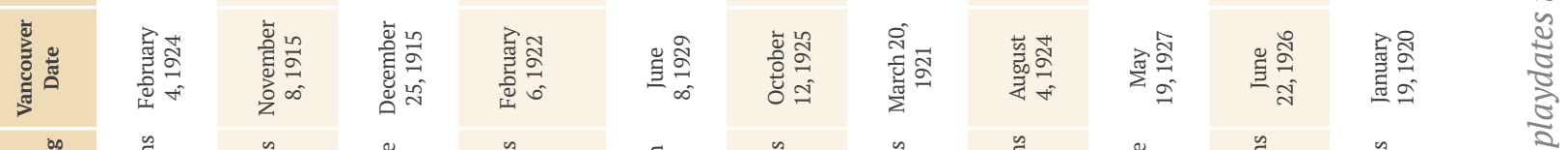

Il

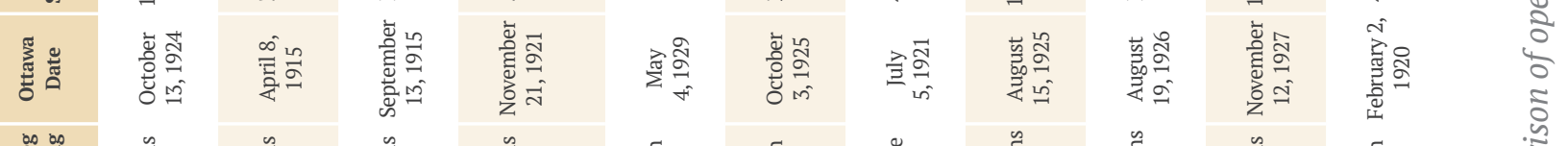

Mll

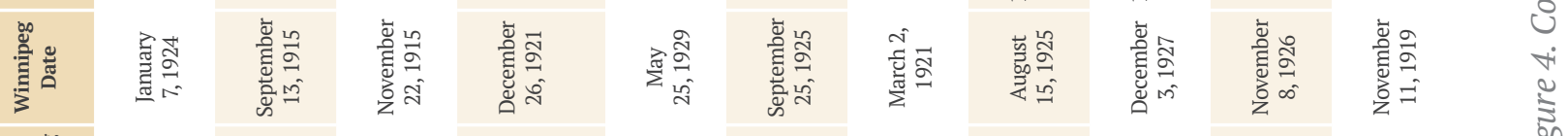

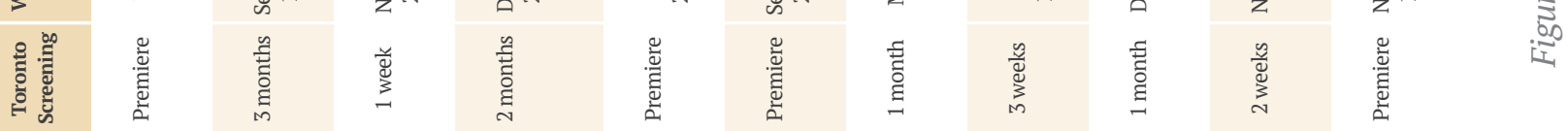

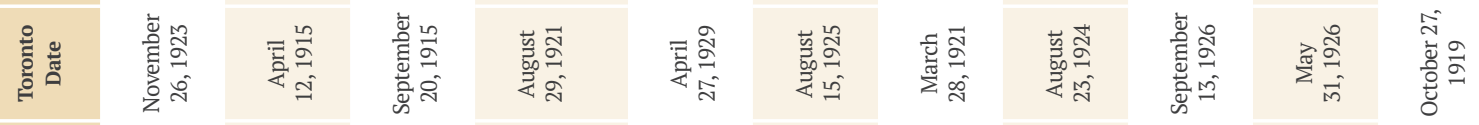

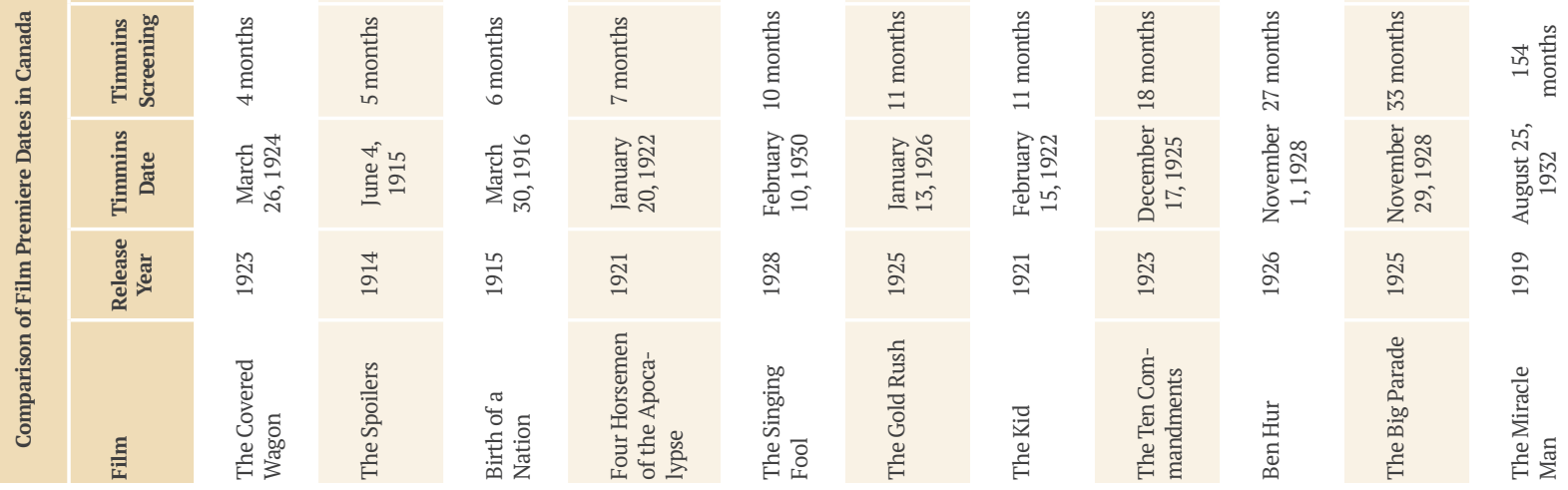


audiences. When films from the Detroit theatres were advertised in the Windsor newspaper there would usually be some type of special promotion to encourage Canadians to cross the border to see these films. For example, when Ben Hur opened in Detroit, the advert in the Windsor paper stated that all patrons traveling on the bus to Detroit would be able to take special cars for 'Ben Hur parties' from the station to and from the theatre (Figure 5).

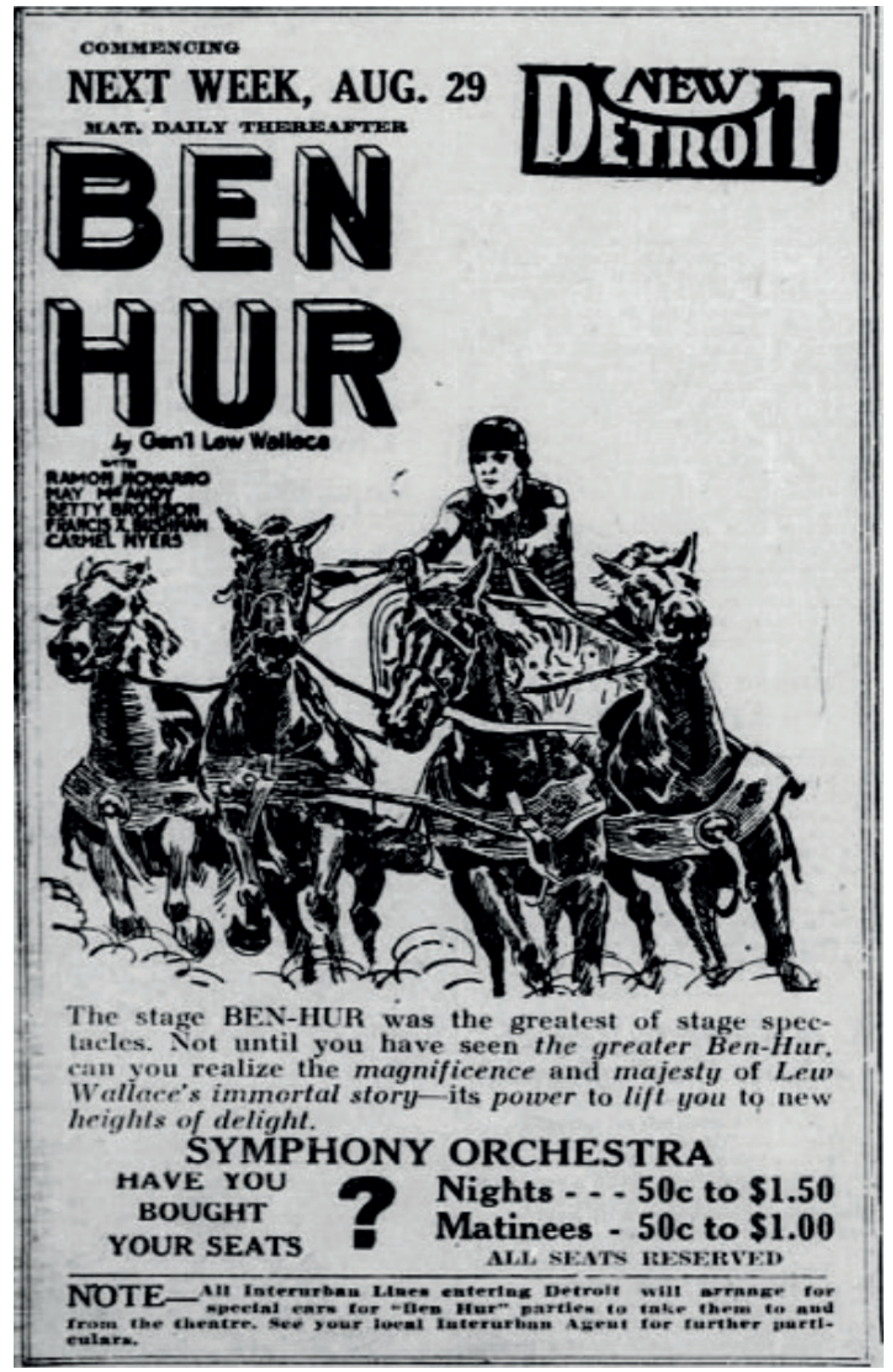

Figure 5. Advertisement for Ben Hur in the Windsor newspaper. The Windsor Star, 28 August 1926, 28. 
TMG 23 (1/2) 2020

Fessica Whitehead

Despite the fact that not all of the top movies were screened in Toronto first, Toronto was often used as an example when popular movies arrived in a new city. In fact, when the Four Horsemen of the Apocalypse, which actually premiered first in Montreal, was screened in Ottawa there was an advertisement in the Ottawa Citizen with the headline "What Toronto Said," and the advert contained quotes from the Toronto newspapers on the success of the movie (Figure 6). Toronto's theatres were

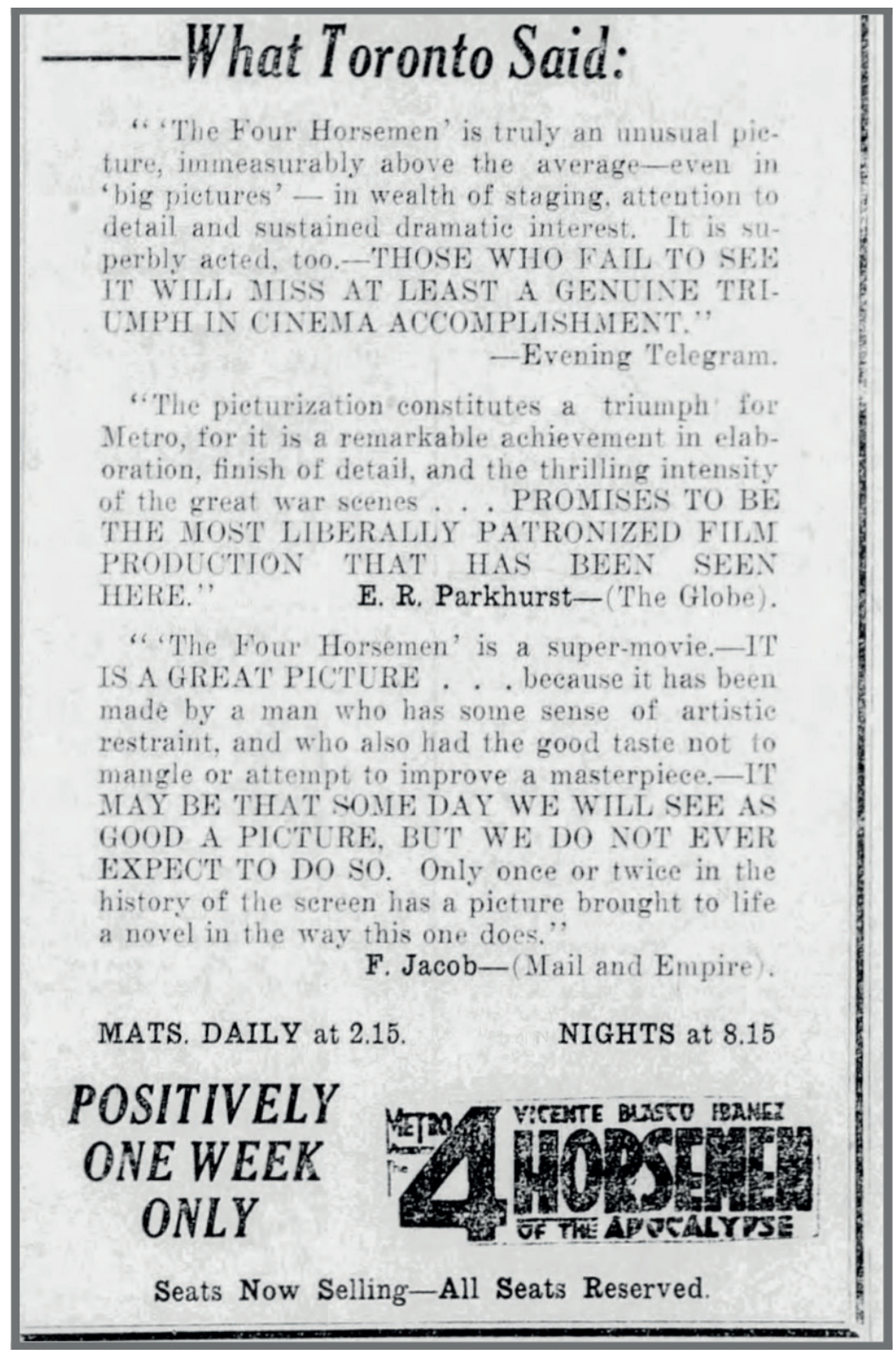

Figure 6. Advertisement from Ottawa Newspaper. The Ottawa Citizen,18 November 1921, 12. 
the flagships in the Paramount controlled Famous Players Canadian chain, and the city was also the base for much of the film distribution offices in the country although there were also exchange offices in Saint John, Montreal, Toronto, Winnipeg, Calgary, and Vancouver, which would distribute prints to local theatres. Although other cities like Ottawa would mention that Toronto had played certain films first, Toronto newspapers on the other hand, did not report when a film had opened in another Canadian city first. For example, when the Big Parade opened in Toronto after Montreal, the Toronto Star only noted that it had played in New York and London, England before coming to Toronto.

Toronto may have been a bellwether for English Canada although this may not have always permeated to the regular movie fan. In an interview, conducted with a moviegoer who remembered going to the theatres in Timmins in the 1930s, they reflected on the fact that it did not matter to people in the town that it took several months for a film to be exhibited in Timmins. He said:

Mascioli because of the cost of a first-run film could get the comedies as first-run, but he didn't want to pay for 'Gone with the Wind' and its first go-around and the circuit. And it made sense because they were charging top dollar for it and all he had to do was wait a month or two and we had no other choice, he had no competition, so it didn't matter. And we didn't know about early releases and all the technical side of the business. All we knew was, 'Gone with the Wind is playing. Let's go out and see it.' We didn't know that it had been out for months and shown in Toronto and Montreal and Vancouver and we were getting it months later. It didn't matter to us. ${ }^{42}$

This quote reflects the fact that perhaps people outside of large cities in Canada were not necessarily engaged with what was showing in places like Toronto despite some newspaper reports to the contrary. While today movies come out simultaneously across the country during much of the history of film exhibition in Canada there was a wide disparity in release dates even in urban Canada as my research shows.

As mentioned above, Famous Players came to dominate film distribution in the 1920s with Nathanson's control of Famous Players-Lasky, distributors of Paramount, and also Regal Films Ltd., which distributed MGM and RKO (and their earlier ancestors), and also Warner at one point. In most cases, prints would be sent to the different exchange offices around the country and then sent to local theatres. From comparing the playdates of Timmins to urban Canada, it is interesting to note that 
some popular films were not screened in Timmins until years or even decades later. The Miracle Man premiered in Toronto in 1919 and did not play in Timmins until the 1930s. In addition, Ben Hur and The Big Parade both took two years to get to Timmins. Two films that played in Timmins relatively close to their release dates were Birth of a Nation and The Spoilers, which were both part of roadshows and did not operate through the usual exchange offices. The Covered Wagon is another exception and it played in Timmins only four months after its premiere in Toronto, and in fact played in Timmins before Ottawa. It was distributed through Famous Players and in many ways demonstrates the complicated nature of tracking premiere dates during this period. The variance in premiere dates among the top films of the tens and twenties shows that there does not seem to be a clear discernible pattern for how films opened and were distributed across the country.

\section{Film programming at Christmas and Easter: Timmins compared with locations in Canada 1919-1929}

Although the films on the best seller list took several months to years to get to Timmins, a key question for my research is: would this also be the case with less expensive films, films on their second release, or for shorts? This is important to determine to see if the lag in film openings in Timmins was because of the high cost of first run popular films, and I wanted to determine if other types of films would open in Timmins more quickly. Also, I wanted to examine if holiday films that were screened during holidays in Timmins were comparable to other locations in Canada? In order to answer these questions, I compiled complete programming data from all the theatres in Timmins during Christmas and Easter and compared this programming to my earlier list of locations in Canada. Both Christmas and Easter were two of the most profitable times of the year for theatres across North America based on box office data. In Timmins, both of these holidays were usually large events at the theatres with full-page ads celebrating the programming for the holiday shows. During Christmas, a Santa Claus would often be a part of the holiday programming and there would also be some type of musical act during the Easter season. The movies that were shown during the holidays were special and often old favourites were brought back or there would be a religious theme to the films screened.

Christmastime became one of the most important times of year for consumer culture in the twentieth century. Something that sets Timmins apart is that the theatres in the town became central 
to Christmas consumer celebrations. While Christmas was still very important to theatres in the rest of Canada, larger cities like Toronto and Winnipeg, relegated information about the Christmas offerings at movie theatres to the picture pages, and during the holidays, there was generally not significant extra advertising. In the Porcupine Advance Christmas issue there would often be extra articles and advertising celebrating the programming and special events at the theatres (Figure 7). Easter was also an important consumer holiday, and again, the Timmins theatres would often have extra advertising and articles on special programming during that holiday as well. Moviegoing in Timmins was closely linked to holiday celebrations and many of my interview subjects, who attended the theatres between 1930 to 1980, remarked that going to movies was an integral part of holiday traditions. In fact, many interview subjects remembered that on Christmas Day children in the town would go to the movies as part of a yearly ritual. ${ }^{43}$

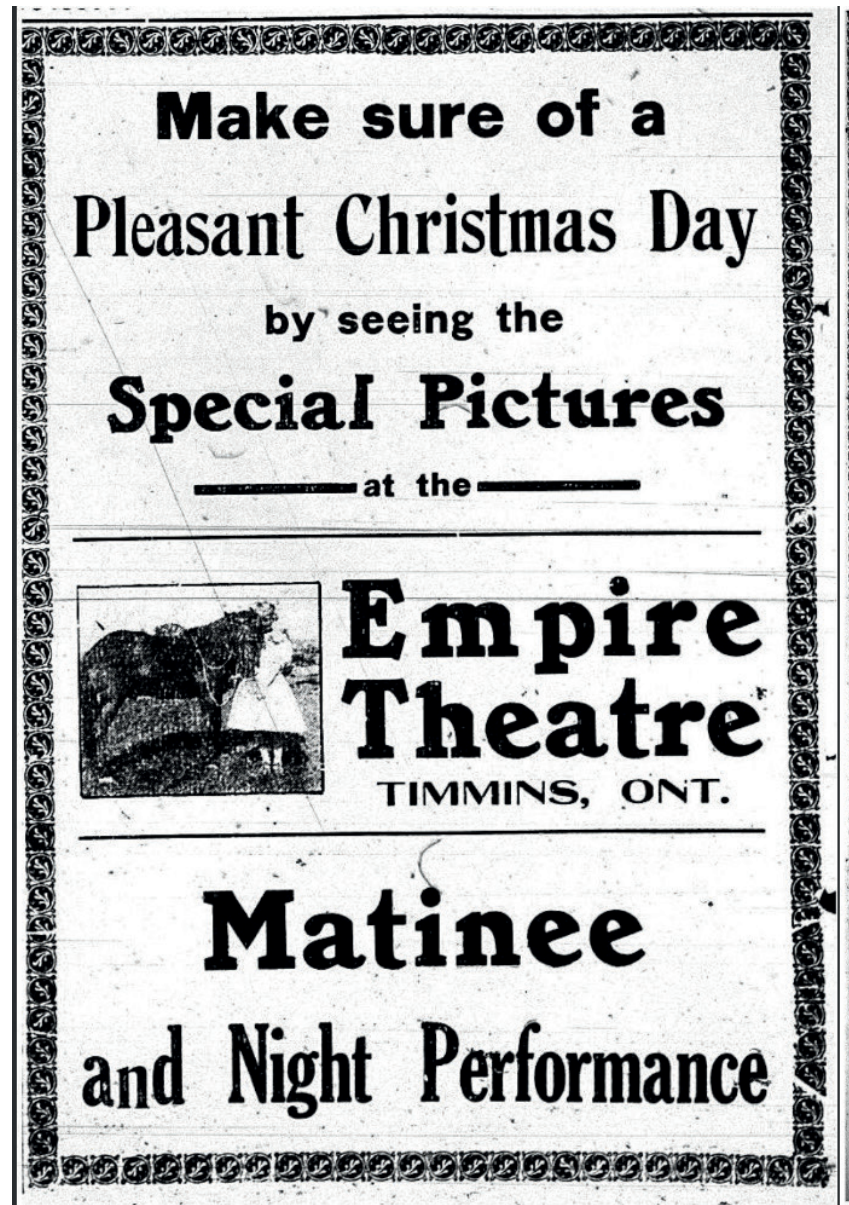

The Porcupine Advance New Empire Theatre CHRISTMAS TREAT for the CHILDREN

Through the kindness of the New Empire Theatre, The Porcupine Advance has been able to arrange a Christmas Treat for the pupils of the Separate and Public Schools of the District. This treat will be known as "The Porcupine Advance and New Empire Theatre Treat for the Children." It will be a motion picture entertainment free to all the Public and Separate School Chil-

The New Empire Theatre Timmins, at 2.30 p.m. on

Friday, December 21st There will be Appropriate Motion Pictures Santa Claus Will be There

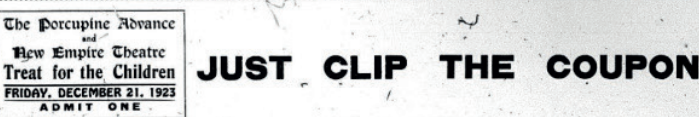


From 1919 to 1929, I recorded the films that played at each theatre in the town of Timmins during these crucial holidays and searched when these same films screened in the rest of Canada during the same year (Figure 8). In addition to feature films, I also recorded short films or animated series advertised in the newspaper. Because most of these films were well past their premiere dates, I wanted to determine if they were part of a second release to see how long films would take to get to Timmins on subsequent tours. I also wanted to see if any of these films played in other locations during the holidays. I used Newspapers.com, which is a comprehensive database that includes a selection of twenty-two Canadian newspapers from both urban locations such as Ottawa and Montreal to smaller more remote locations such as Nanaimo, British Columbia and Red Deer, Alberta.

Figure 8 reflects all of the holiday programming at the Timmins theatres and when the film played in other locations in Canada during the same year (in some cases these were premieres but in most cases the films were part of a subsequent tour). A large portion of the films that were screened in Timmins during the holidays were in the midst of a second or even third Canadian run. In most cases these films played in the town two to four months after other Canadian locations. Although there were several examples of both films having their first or only screening in Timmins for that year as well as films coming to Timmins seven to eleven months after being screened in another Canadian location. Some of the shorts and animated series that played in Timmins were years out of date and it was the only location where they were screened.

A key question that I had was if holiday films in Timmins were unique or consistent with other locations. Today, it is typical for holiday films to be collectively viewed across Canada, and I wanted to determine if in the past there were any commonalities between holiday films. From this research, I determined that the vast majority of the holiday films in Timmins did not play in other locations at the same time. Although again there were some exceptions. In 1922, D. W. Griffith's Orphans of the Storm, also played in Vancouver at Christmas and in 1923, Ernst Lubitsch's Rosita played in both Timmins and Winnipeg at Christmas. Except for these two examples, the holiday films in Timmins were unique from other locations.

Despite Timmins' relatively multicultural population made up of immigrant miners, the theatres like others in cities and towns across English Canada had typical programming with Hollywood films playing nightly. All but one of the films that played at the theatres during the holidays were from Hollywood. The only non-Hollywood film was the 1923 British silent drama I Will Repay, which played in Timmins during Easter of 1925. Out of the approximately fifty films collected 


\begin{tabular}{|c|c|c|c|c|}
\hline Film & $\begin{array}{l}\text { Release } \\
\text { Year }\end{array}$ & Timmins Playdate & Comparison to other locations & Film Genre \\
\hline Birth of A Nation & 1915 & April 11, 1919 & 3 months after playing in Montreal & Drama \\
\hline Riders of the Law & 1919 & December 24, 1919 & 1 month after playing in Montreal & Western \\
\hline Monkey Stuff & 1919 & December 24, 1919 & 4 months after playing in Winnipeg & Short Comedy \\
\hline $\begin{array}{l}\text { Rough Riding } \\
\text { Romance }\end{array}$ & 1919 & April 3, 1920 & 3 months after playing in Ottawa & Western \\
\hline The Confession & 1920 & December 24, 1920 & 10 months after playing in Montreal & Drama \\
\hline Out of the Storm & 1920 & April 25, 1921 & 2 months after playing in Edmonton & Drama \\
\hline $\begin{array}{l}\text { The Conquering } \\
\text { Power }\end{array}$ & 1921 & April 15, 1922 & 3 months after Winnipeg & Drama/Romance \\
\hline Doggone Torchy & 1921 & April 15, 1922 & First location in 1922 & Short Comedy \\
\hline $\begin{array}{l}\text { Orphans of the } \\
\text { Storm }\end{array}$ & 1921 & December 24, 1922 & 3 months after playing in Ottawa & Drama/Romance \\
\hline $\begin{array}{l}\text { One Exciting } \\
\text { Night }\end{array}$ & 1922 & March 31, 1923 & 2 months after playing in Windsor & Mystery \\
\hline Rosita & 1923 & December 25, 1923 & 2 months after playing in Ottawa & Romance/Comedy \\
\hline $\begin{array}{l}\text { Orphans of the } \\
\text { Storm }\end{array}$ & 1921 & December 25, 1923 & Only location in 1923 & Drama/Romance \\
\hline Three Wise Fools & 1923 & April 11, 1924 & 2 months after Vancouver & Comedy \\
\hline Affinities & 1922 & April 11, 1924 & 3 months after Victoria & Comedy \\
\hline Oh, You Tony! & 1924 & December 24, 1924 & 2 months after playing in Saskatoon & Comedy/Western \\
\hline Fight and Win & 1924 & December 24, 1924 & 4 months after playing in Montreal & $\begin{array}{l}\text { Fight Picture/ } \\
\text { Drama }\end{array}$ \\
\hline
\end{tabular}




\begin{tabular}{|c|c|c|c|c|}
\hline Film & $\begin{array}{l}\text { Release } \\
\text { Year }\end{array}$ & Timmins Playdate & Comparison to other locations & Film Genre \\
\hline The Mark of Zorro & 1920 & December 24, 1924 & 7 months after playing in Windsor & Western/Adventure \\
\hline The Fast Express & 1924 & December 24, 1924 & Same month as Calgary & Western/Adventure \\
\hline $\begin{array}{l}\text { The City the Never } \\
\text { Sleeps }\end{array}$ & 1924 & April 11, 1925 & 3 months after Victoria & Drama \\
\hline Love Goofy & 1925 & April 11, 1925 & 1 month after playing in Saskatoon & Short Comedy \\
\hline I Will Repay & 1924 & April 11, 1925 & First location in 1925 & Drama \\
\hline One Man Reunion & 1922 & April 11, 1925 & Only location in 1925 & Short Documentary \\
\hline Heads Up & 1925 & April 11, 1925 & First location in 1925 & Adventure \\
\hline Maytime & 1923 & April 11, 1925 & 2 months after playing in Winnipeg & Drama \\
\hline $\begin{array}{l}\text { A Tiny Tour of the } \\
\text { USA }\end{array}$ & 1924 & April 11, 1925 & Only location in 1925 & Animation \\
\hline Tootsie Wootsie & 1924 & April 11, 1925 & 3 months after playing in Edmonton & Short Comedy \\
\hline $\begin{array}{l}\text { The Ten Com- } \\
\text { mandments }\end{array}$ & 1923 & December 25, 1925 & $\begin{array}{l}11 \text { months after playing in Vancou- } \\
\text { ver }\end{array}$ & Drama/Religious \\
\hline Dick Turpin & 1925 & December 25, 1925 & 9 months after playing in Nanaimo & Adventure \\
\hline $\begin{array}{l}\text { The Man Who } \\
\text { Found Himself }\end{array}$ & 1925 & April 4, 1926 & 2 months after playing in Ottawa & Drama \\
\hline Calgary Stampede & 1925 & April 4, 1926 & 3 months after playing in Winnipeg & Western/Adventure \\
\hline The Midnight Sun & 1924 & December 25, 1926 & 2 months after playing in Ottawa & Short Documentary \\
\hline $\begin{array}{l}\text { Tillie's Punctured } \\
\text { Romancê̂A }\end{array}$ & 1914 & December 25, 1926 & Only location in 1926 & Comedy \\
\hline
\end{tabular}




\begin{tabular}{|c|c|c|c|c|}
\hline Film & $\begin{array}{l}\text { Release } \\
\text { Year }\end{array}$ & Timmins Playdate & Comparison to other locations & Film Genre \\
\hline $\begin{array}{l}\text { The Arizona } \\
\text { Streak }\end{array}$ & 1926 & April 16, 1927 & Only location in 1927 & Western \\
\hline Ukulele Sheiks & 1927 & April 16, 1927 & First location in 1927 & Short Western \\
\hline $\begin{array}{l}\text { Tenderfoot Cour- } \\
\text { age }\end{array}$ & 1927 & April 16, 1927 & First location in 1927 & Short Western \\
\hline $\begin{array}{l}\text { Eucharistic Con- } \\
\text { gress of Chicago }\end{array}$ & 1926 & April 16, 1927 & First location in 1927 & Drama/Religious \\
\hline Cameo Kirby & 1923 & December 24, 1927 & 3 months after playing in Ottawa & Western \\
\hline 30 Below Zero & 1926 & December 24, 1927 & 9 months after playing in Regina & Western \\
\hline Les Miserables & 1922 & April 6, 1928 & 3 months after playing in Winnipeg & Short Drama \\
\hline His First Flame & 1927 & April 6, 1928 & 3 months after playing in Windsor & Comedy \\
\hline $\begin{array}{l}\text { The Opening } \\
\text { Night }\end{array}$ & 1927 & December 25, 1928 & 10 months after playing in Ottawa & Drama \\
\hline The Count & 1916 & December 25, 1928 & Only location in 1928 & Short Comedy \\
\hline Frenzy & 1928 & December 25, 1928 & 9 months after playing in Regina & Short Drama \\
\hline $\begin{array}{l}\text { Red Riders of } \\
\text { Canada }\end{array}$ & 1928 & December 25, 1928 & 7 months after playing in Calgary & Western \\
\hline $\begin{array}{l}\text { Man Without a } \\
\text { Face }\end{array}$ & 1928 & $\begin{array}{l}\text { December 25, } \\
1928\end{array}$ & 4 months after playing in Ottawa & Adventure \\
\hline Fish Stories & 1928 & $\begin{array}{l}\text { December 25, } \\
1928\end{array}$ & Only location in 1928 & Short Comedy \\
\hline Napoleon & 1927 & April 1, 1929 & $\begin{array}{l}1 \text { month after playing in Win- } \\
\text { nipeg }\end{array}$ & Historical Drama \\
\hline
\end{tabular}

(Continued) 


\begin{tabular}{|l|l|l|l|l|}
\hline Film & $\begin{array}{c}\text { Release } \\
\text { Year }\end{array}$ & Timmins Playdate & Comparison to other locations & Film Genre \\
\hline Yellow Lily & 1928 & April 1, 1929 & $\begin{array}{l}4 \text { months after playing in Win- } \\
\text { nipeg }\end{array}$ & Romance Drama \\
\hline Broadway & 1929 & $\begin{array}{l}\text { December 25, } \\
1929\end{array}$ & $\begin{array}{l}\text { 6 months after playing in Van- } \\
\text { couver }\end{array}$ & Musical \\
\hline Show Girl & 1928 & $\begin{array}{l}\text { December 25, } \\
1929\end{array}$ & $\begin{array}{l}11 \text { months after playing in Re- } \\
\text { gina }\end{array}$ & Comedy/Drama \\
\hline
\end{tabular}

for this research, only two were set in Canada and both of them were American productions. The first Canadian-themed film to be screened was the 1925 film, The Calgary Stampede, which was shown in Timmins during Easter of 1926. Universal Pictures produced this film with parts of it shot in Calgary. The other Canadian-themed film that played during Christmas of 1928 was Red Riders of Canada. This film was originally released in April 1928 by FBO Pictures Corporation.

As mentioned above, all but one of the films shown were from Hollywood, but there were several different genres that were played during the holidays. I used IMDB to categorise the films by genre and I found that a significant portion of the films that played in Timmins during the holidays were western or adventure type films. Out of all the films played during the holidays, 42 percent can be identified as action films (Figure 9). This was the largest percentage of any type of film played at the theatres. Westerns also seem to be a genre of film that screened relatively quickly after their release dates in Timmins. For example, Harry Carey's The Rider of the Law premiered in Timmins a month after it was released. Also, the western short Tenderfoot Courage played in Timmins before any other location in the newspaper.com database.

As Richard Maltby points out, during the classical Hollywood era, it was bookers who mostly categorised film audiences and there was a difference between what was marketed to urban audiences and those in small towns. ${ }^{44}$ In Canada, films were distributed through sales offices based in different regions in the country with all of the central offices located in Toronto. Timmins being an Ontario town was serviced through the offices in Toronto and sales agents would travel to the town to sell their pictures. Because the Mascioli chain was independent during this period, they had some 


\section{Films Played During the Holidays}

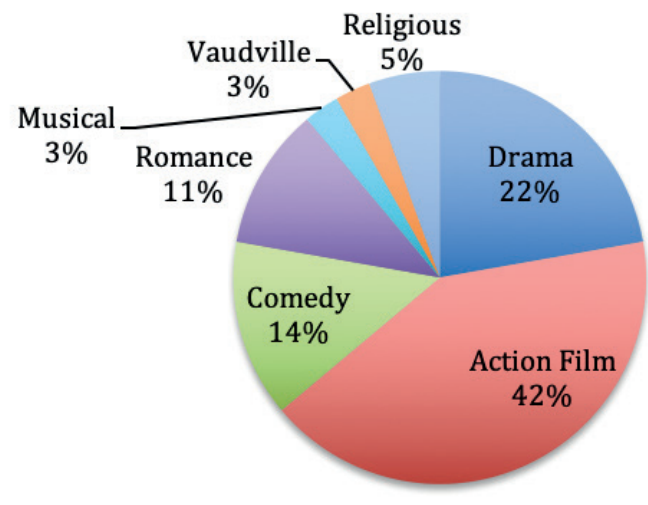

Figure 9. Holiday films categorised by genre in Timmins from 1912 to 1930.

autonomy on what types of films to rent based on their audience as well as what was being offered by the sales office in addition to price constraints. Thus, it was likely a combination of what was being offered by sales agents and bookers as well as Mascioli himself that would determine the types of films that played in Timmins.

Another common type of film during the holidays was productions by D. W. Griffith. On three separate occasions, Griffith's films played during the holidays in 1919, 1922, and 1923. Birth of a Nation played during Easter of 1919, and this was at least the third time the film was shown in Timmins during the 1910s. This deeply racist film maintained its popularity years after its release in 1915, and Timmins was one of several places in North America to screen the film during Easter of 1919; another was Dubuque, Iowa. ${ }^{45}$ For Christmas of 1922 and 1923, Orphans of the Storm played at the theatres. Orphans of the Storm was a very popular film that was released in 1921, but it continued to play in theatres across North America in 1923, including in Ottawa in March of that year. In 1923, the 1922 feature One Exciting Night played during Easter. Griffith films, of course, were extremely popular globally, but it is notable that his films were often chosen to play during the holidays in Timmins.

Another common occurrence at the Timmins theatres was that many old favourites were brought back during the holidays. In addition to Birth of a Nation and Orphans of the Storm being rescreened years after they were first released, the films Tillie's Punctured Romance, The Count, and Les 
Miserables all played in Timmins a decade after they were released. Tillie's Punctured Romance, first released in 1914 played in Timmins during Christmas of 1926 and The Count, first released in 1916 was screened during Christmas of 1928. For both Tillie's Punctured Romance and The Count, they did not appear to be released elsewhere in Canada as part of a new tour. The playing of old favourites was almost exclusively done during Christmas, and in comparison, with other holidays, there was only one example of a repeat screening of a favourite film during Easter.

\section{Conclusions}

By comparing film release dates in Canada, this research demonstrates that although Toronto, the headquarters of film distribution in the country, most often had the Canadian premiere for films, there was a lot of variance to what cities would host the Canadian premiere. The largest city in Canada, Montreal, occasionally screened films first and there were also examples of Ottawa, Vancouver, Winnipeg, and Detroit theatres outside of Windsor screening films before Toronto. What is clear, is that remote areas like Timmins generally screened popular films months or even years after they premiered in urban Canada. Although this also sometimes happened in cities like in Montreal when The Ten Commandments was first screened almost a year after it opened in Toronto.

At first glance this analysis tells a story that one would assume; that films opened much later in small town and remote locations vs urban locations, but there is also more to the story. The moviegoing habits of people in the town of Timmins did differ from their urban counterparts and specifically showed unique attributes during Christmas. Theatres in Timmins, which was true in other small towns across North America, were the centre of social life in the town. The holiday programming, which often brought back old favourites at Christmastime, is reflective of this. Despite the fact that they would not have access to contemporary first run films, people in Timmins would regularly watch known crowd-pleasers during the holidays. It is also interesting to note that certain genres like Western films were screened in Timmins more quickly after their release dates.

The comparative data collected for this research was from a time period before Timmins had been fully integrated into the Famous Players Canadian circuit. While this research shows that there was a variance between opening playdates in urban Canada during the formative period of standardised film exhibition in Canada, further research needs to be done after vertical integration 
was complete, and how this affected the variance of playdates across the country. Interestingly, what we can see from the looking at the top films of the 1910s and 1920s, is that there is not a discernible pattern of distribution. While most films did open up in Toronto first, only four out of the thirteen films did so with several other Canadian cities also having more than one premiere. Some of these rival premieres were due to the shifting nature of the period like when The Kid opened in Winnipeg at the Allen Theatre because it was a First National picture. Other times films that were part of roadshows also would open up in cities other than Toronto. This comparative research shows that film exhibition and distribution in Canada was far more complex than previously thought and more research and comparative data needs to be compiled to tell the rest of the story.

\section{Notes}

1 See: Jessica L. Whitehead, “The Business of 'Wholesome Entertainment': The Mascioli Film Circuit of Northeastern Ontario," in Rural Cinema Exhibition and Audiences in a Global Context ed. Daniela Treveri Gennari, Danielle Hipkins, Catherine O’Rawe (London, UK: Palgrave Macmillan, 2018), 47-70.

2 Daniel Biltereyst and Philippe Meers, "New Cinema History and the Comparative Mode: Reflections on Comparing Historical Cinema Cultures," Alphaville 11 (2016): 13-32.

3 Biltereyst and Meers, “New Cinema History,” 14-15.

4 Stefan Berger, “Comparative history,” in Writing History: Theory and Practice, ed. Heiko Feldner, Kevin Passmore, Stefan Berger (New York, NY: Bloomsbury, 2003): 162.

5 See: Kathryn H. Fuller, At the Picture Show: Small-town Audiences and the Creation of Movie Fan Culture. (Washington, DC: Smithsonian Inst Press, 1996). Robert C. Allen, "Race, Region, and Rusticity: Relocating U.S. Film History," in Going to the Movies: Hollywood and the Social Experience of Cinema, ed. Richard Maltby et al., 25-45 (Exeter UK: University of Exeter Press, 2007); Gregory A. Waller, “Imagining and Promoting the Small-Town Theater." Cinema Journal 44, no. 3 (2005): 3-19; Jeffery Klenotic, "From Mom-and-Pop to Paramount Publix: Selling the Community on the Benefits of National Theatre Chains," in Watching films: New Perspectives on Movie-going, Exhibition and Reception, ed. Karina Aveyard and Albert Moran, 189-209 (Bristol, UK: Intellect, 2013); Judith Thissen and Clemens Zimmermann, eds., Cinema beyond the City. Bloomsbury Publishing, 2017; Meers, Philippe, Daniel Biltereyst, and Lies Van De Vijver. “Metropolitan vs Rural Cinema Going in Flanders, 1925-75.” Screen 51, no. 3 (2010): 272-280; Daniela Treveri Gennari, 
Danielle Hipkins Catherine O’Rawe, eds., Rural Cinema Exhibition and Audiences in a Global Context (London, UK: Palgrave Macmillan, 2018).

6 See: Gregory Canning, "Moving Pictures at the Opera House: The Introduction of Motion Pictures to the Town of Truro, Nova Scotia, 1897-1914," in Rain/Drizzle/Fog: Film and Television in Atlantic Canada, ed. Darrell Varga (Calgary, AB: University of Calgary Press, 2009), 47-67; Charles Tepperman, “Digging the Finest Potatoes from Their Acre: Government Film Exhibition in Rural Ontario," in Hollywood in the Neighborhood: Historical Case Studies of Local Moviegoing, ed. Kathryn Fuller-Seeley (Berkeley, CA: University of California Press, 2008), 130-149.

7 I am relying on population figures published in The Porcupine Advance. For these figures see: "Timmins Population 3,839," The Porcupine Advance, January 16, 1922, 7. “Timmins Population Down Over 4,000 From Last Year," The Porcupine Advance, October 21, 1943 (second section), 1. The population in Timmins hit a peak in 1941 due to a boom in mining and in the following years began to decline as mining production declined.

8 See: Manjunath Pendakur, Canadian Dreams and American Control: The Political Economy of the Canadian Film Industry (Detroit MI: Wayne State University Press, 1990); Ian Jarvie, Hollywood"s Overseas Campaign: The North Atlantic Movie Trade, 1920-1950 (Cambridge, UK: Cambridge University Press, 1992); Michael Dorland, So Close to the State/s: The Emergence of Canadian Feature Film Policy (Toronto, ON: University of Toronto Press, 1998); Ted Magder, Canada's Hollywood: The Canadian State and Feature Films, (Toronto, ON: University of Toronto Press, 1993).

9 Ira Wagman “On the Policy Reflex in Canadian Communication Studies," Canadian Journal of Communication 35, no. 4 (2010): 619-630.

10 Zoë Druick, Projecting Canada: Government Policy and Documentary Film at the National Film Board (Montreal, QU: McGill-Queen”s Press, 2007).

11 Monika Gagnon and Janine Marchessault, eds., Reimagining Cinema: Film at Expo 67 (Montreal, QU: McGillQueen”s University Press, 2014).

12 For example: Louis Pelletier, "Early Quebec Actualities and the Ephemeral Meaning of Moving Images in the Transitional Era," in Cinephemera: Archives, Ephemeral Cinema, and New Screen Histories in Canada, ed. Zöe Druick et al. (Montreal QU: McGill-Queen”s Press, 2014). Peter Lester, “Sweet Sixteen Goes to War: Hollywood, the NAAF and 16mm Film Exhibition in Canada During WWII," Canadian Journal of Film Studies 19, 1 (2010): 2-19. 
13 See: Paul S. Moore, "Mapping the Mass Circulation of Early Cinema: Film Debuts Coast-to-Coast in Canada in 1896 and 1897," Canadian Journal of Film Studies 21, No. 1 (2012): 58-80.

14 Paul S. Moore "Movie Palaces on Canadian Downtown Main Streets: Montreal, Toronto, and Vancouver,” Urban History Review/ 32, no. 2 (2004): 3-20. Paul Moore, “Nationalist Film-going without Canadian-made Films?" in Early Cinema and the National, ed. Richard Abel et al. (John Libbey Publishing, 2008), 155-163. Paul S. Moore, “The Social Biograph: Newspapers as Archives of the Regional Mass Market for Movies," in Explorations in New Cinema History, ed. Richard Maltby, Daniel Biltereyst and Philippe Meers (Malden, MA: Wiley-Blackwell, 2011), 263-279.

15 Paul Moore, Now Playing: Early Moviegoing and the Regulation of Fun (Buffalo, NY: SUNY Press, 2008), 5.

16 As noted above, there are some exceptions such as: Canning, "Moving Pictures at the Opera House" and Tepperman, "Digging the Finest Potatoes."

17 For comparative pieces see: Paul Moore, “The Social Biograph: Newspapers as Archives of the Regional Mass Market for Movies,” in Explorations in New Cinema History, 269-279; Paul Moore, “Nationalist Filmgoing without Canadian-Made Films?” in Abel, King \& Bertollini, eds., Early Cinema and the National (Eastleigh, UK: John Libbey Press, 2008), 155-163).

18 Pendakur, Canadian Dreams American Control, 45.

19 Ibid.

20 Paul Moore, Now Playing: Early Moviegoing and the Regulation of Fun (Buffalo, NY: SUNY Press, 2008), 98.

21 Paul S. Moore, "Mapping the Mass Circulation of Early Cinema: Film Debuts Coast-To-Coast in Canada in 1896 and 1897," Canadian Journal of Film Studies 21, no. 1 (2012): 68.

22 These films were made by British filmmaker and exhibitor F. Guy Bradford and his assistant Joseph Rosenthal and films shot in 1902 were part of the Living Canada series commissioned by the Canadian Pacific Railway.

23 From newspaper reports shared with author.

24 Doug Baldwin, “A Study in Social Control: The Life of the Silver Miner in Northern Ontario.” Labour 2 (1977): 99.

25 The only licensed liquor providers were hotels in the nearby town of Haileybury, Ontario.

26 W. M, Gladish, “Where the Lights Are Northern,” The Moving Picture World. March 8, 1919, 1325.

27 “Four Dollars Receipts at First Movies Here; Used Renovated Store.” Timmins Daily Press, March 27, 1939, p. 1.

28 “Empire Theatre Coming Attractions," Porcupine Advance (1915, December 23), p. 2. 
“To Accommodate Picture Enthusiasts,” The Porcupine Advance April 6, 1921, p. 1.

30 Nancy Forestell, “Bachelors, Boarding Houses and Blind Pigs: Gender Construction in a Multiethnic Mining Camp, 1909-1920," in A Nation of Immigrants, Women, Workers and Communities in Canadian History, 1840s-1960s, ed. F. Iacovetta, P. Draper and R. Ventresca (Toronto, ON: University of Toronto Press), 251-290, there 253 .

31 Moore, “Mapping Mass Circulation,” 59.

32 Jeffery Klenotic, "From Mom-and-Pop to Paramount Publix."

33 Douglas Gomery, “US Film Exhibition,” 219.

34 Data from Ancestry.com, 1921 Census of Canada.

35 See: Paul S. Moore, “Nathan L. Nathanson Introduces Canadian Odeon: Producing National Competition in Film Exhibition," Canadian Journal of Film Studies 12, no.2 (2003): 22-45.

36 Seiler, "Nathanson, Zukor, and Famous Players," 64.

37 Peter White, Investigation into an Alleged Combine in the Motion Picture Industry in Canada (Ottawa, ON: Printer to the King”s Most Excellent Majesty, 1931), 13.

38 Pendakur, Canadian Dreams and American Control, 69.

39 Ibid, 76.

40 In the 1930s, the Janet Gaynor version of Daddy Long Legs played in Timmins but not the 1919 Pickford release it seems.

41 "Popular Prices at Future Attractions," Ottawa Citizen, October 16, 1924, p. 5.

42 Interview conducted on July 22, 2015. All interviews for this research were given REB approval and respect the Canadian Tri-council Policy on the Ethical Conduct for Research Involving Human Participants.

43 Interview conducted on July 15, 2015.

44 Richard Maltby, "Sticks, Hicks and Flaps: Classical Hollywood's Generic Conception of its Audiences," in Identifying Hollywood's Audiences: Cultural Identity and the Movies, ed. M. Stokes and R. Maltby (London: BFI, 1999), 23-41.

45 For more information on the controversy surrounding the film see: Melvyn Stokes, $D$. W. Griffith's The Birth of a Nation: A History of the Most Controversial Motion Picture of All Time (Oxford, UK: Oxford University Press, 2007). 


\section{Biography}

Jessica Leonora Whitehead is a Faculty Liaison providing pedagogical support at the University of Toronto in the Faculty of Arts \& Science. Her research focuses on screen cultures in North America, and her work has appeared in the Canadian Journal of Film Studies, Transformative Works and Cultures, Italian Canadiana, and chapters in the books Rural Cinema-going from a Global Perspective and Mapping Movie Magazines. She is currently working on a book project exploring Italian-Canadian cinema cultures for McGill-Queen's Press.

TMG Journal for Media History

Volume 23 No $(1 / 2) / 2020$

DOI

http://dx.doi.org/10.18146/2213-0969.2020.TMG202016

\section{PUBLISHER}

Netherlands Institute for Sound and Vision

\section{COPYRIGHT}

Each article is copyrighted (c) by its author(s) and is published under license from the author(s). When a paper is accepted for publication, authors will be requested to agree with the Creative Commons Attribution 4.0 International License. 